\title{
Enzymatic Metabolism of Nitrogen in Leaves and Roots of Creeping Bentgrass under Nitrogen Deficiency Conditions
}

\author{
Zhongchun Jiang ${ }^{1}$, Chenping $\mathrm{Xu}$, and Bingru Huang ${ }^{2}$ \\ Department of Plant Biology and Pathology, Rutgers University, 59 Dudley Road New Brunswick, \\ NJ 08901
}

\begin{abstract}
AdDitional INDEX wORDs. glutamate dehydrogenase, glutamine synthetase, grass, nutrient deficiency
Abstract. Low nitrogen (N) rates are recommended for creeping bentgrass (Agrostis stolonifera) putting greens to prevent excessive shoot growth and potential nitrate leaching, but low $\mathbf{N}$ rates could lead to $\mathbf{N}$ deficiency, which induces leaf senescence. This study was conducted to examine the effects of $\mathbf{N}$ deficiency on two enzymes involved in organic $\mathrm{N}$ metabolism as well as amino acid (AA) and soluble protein (SP) contents in both young and old leaves and roots of creeping bentgrass. Creeping bentgrass plants (cv. Penncross) were grown in a nutrient solution containing either $6 \mathrm{~mm}$ nitrate $(+\mathrm{N}$ plants) or zero $\mathrm{N}(-\mathrm{N}$ plants), and each of the two treatments had four replicate pots. Young leaves on upper portions of the stolons and old leaves on lower portions of the stolons were separated and sampled at 14, 21, and 28 days of treatment, and roots were sampled at 28 days. Nitrogen deficiency increased glutamine synthetase (GS) transferase activity in all three tissues and at all three dates and GS biosynthetic activity in young leaves at all three dates. Prolonged $\mathbf{N}$ deficiency at 21 and 28 days increased glutamate dehydrogenase (GDH) deamination and amination activities in old leaves. In the roots, $\mathbf{N}$ deficiency at 28 days increased GS transferase activity but decreased GDH deamination activity. The $\mathrm{N}$ deficiency decreased AA content in all three tissues and at all three dates and SP content in young leaves at all three dates and in old leaves at 21 and 28 days. Decreasing organic $\mathrm{N}$ reserves in AA and SP and increasing GS and GDH activities in senescing leaves may be adaptive responses to $\mathrm{N}$ deficiency.
\end{abstract}

Nitrogen is an essential mineral nutrient for plant growth and development and is often a limiting factor in maintaining highquality putting greens on golf courses. Because of environmental concerns and decreased root growth at high $\mathrm{N}$, low rates of $\mathrm{N}$ fertilization are recommended, particularly for sites that are prone to excessive leaching. However, reduced use of $\mathrm{N}$ fertilizers could lead to $\mathrm{N}$ deficiency, which would increase remobilization of $\mathrm{N}$ within the grass plant for the growth of young leaves as shown by Ourry et al. (1990). They demonstrated that $69 \%$ of the total $\mathrm{N}$ in young leaves of $14-\mathrm{d}-\mathrm{N}$-starved perennial ryegrass (Lolium perenne) came from endogenous $\mathrm{N}$ of the roots and stubble. Bowman (1993) showed that $\mathrm{N}$ deprivation for $7 \mathrm{~d}$ led to redistribution of reduced $\mathrm{N}$ (total $\mathrm{N}$ excluding nitrate-N) from perennial ryegrass roots and verdure to the leaves. Few studies of turfgrass have reported activities of enzymes in organic $\mathrm{N}$ metabolism of young and old leaves of plants under $\mathrm{N}$ deficiency (Lyons et al., 1990; Ourry et al., 1990). Elucidating on this would greatly further our understanding of the mechanisms for efficient $\mathrm{N}$ use by turfgrass.

Organic $\mathrm{N}$ metabolism may be adversely affected by $\mathrm{N}$ deficiency because $\mathrm{N}$ deficiency induces leaf senescence (Lim et al., 2007). In senescing leaves, $\mathrm{N}$ catabolism occurs and proteins are degraded to produce $\mathrm{NH}_{3}$ and amino acids, which

Received for publication 24 June 2011. Accepted for publication 5 Aug. 2011. This study was supported in part by a sabbatical leave granted to $Z$. Jiang by the State University of New York College of Agriculture and Technology at Cobleskill, NY and was conducted at Rutgers University with financial support from Rutgers Center for Turfgrass Science.

We thank Emily Merewitz, David Jespersen, and Patrick Burgess for critical review of the manuscript.

${ }^{1}$ Current address: Department of Plant Science, State University of New York, Cobleskill, NY 12043.

${ }^{2}$ Corresponding author. E-mail: huang@aesop.rutgers.edu. are used to produce glutamine (Gln) for $\mathrm{N}$ transport to young leaves and other sink organs for reuse (Liu et al., 2008). In actively growing leaves, $\mathrm{N}$ anabolism occurs and AAs are used to synthesize proteins and chlorophylls (Chl). Two key enzymes, glutamine synthetase (EC 6.3.1.2) and glutamate dehydrogenase (EC 1.4.1.2), are involved in $\mathrm{N}$ anabolism and catabolism (Miflin and Habash, 2002). Glutamine synthetase catalyzes an ATP-dependent reaction, in which $\mathrm{NH}_{3}$ is combined with glutamate (Glu) to form Gln, which is a major donor of amino $\mathrm{N}$ for the synthesis of other AAs including the regeneration of Glu by glutamate 2-oxoglutarate aminotransferase (GOGAT) in the GS-GOGAT cycle. In higher plants, two isoforms of GS exist: GS1 in the cytosol and vascular bundles, which produces Gln primarily for $\mathrm{N}$ transport from source to sink tissues, and GS2 in chloroplasts and root plastids, which produces Gln primarily for local use (Lam et al., 1996). In addition to assimilating $\mathrm{NH}_{3}$ from root uptake, GS1 plays a key role in $\mathrm{N}$ remobilization in senescing leaves by reassimilating $\mathrm{NH}_{3}$ from the catabolism of AAs (Bernard and Habash, 2009), whereas GS2 plays an important role in photosynthesizing leaves by assimilating $\mathrm{NH}_{3}$ from photorespiration (Wallsgrove et al., 1987) and nitrate reduction (ZozayaHinchliffe et al., 2005).

Glutamate dehydrogenase catalyzes a reversible reaction, in which glutamate is deaminated or 2-oxoglutarate is aminated (Dubois et al., 2003). In the deamination process, glutamate is converted to 2-oxoglutarate with the release of $\mathrm{NH}_{3}$ and the reduction of $\mathrm{NAD}^{+}$to NADH. In the amination process, 2-oxoglutarate is combined with $\mathrm{NH}_{3}$ to produce Glu with the oxidation of NADH to $\mathrm{NAD}^{+}$. The GDH is localized to the mitochondria of phloem companion cells and to the cytosol of senescing leaves and may affect the translocation of assimilates during carbon $(\mathrm{C})$ and $\mathrm{N}$ remobilization or respond to the 
plant's redox status and thus stress level (Dubois et al., 2003). Although GDH primarily catalyzes the catabolism of Glu (Lam et al., 1996), there is strong evidence that the anabolism of Glu by GDH also occurs in plants and that this enzyme may participate in the assimilation and detoxification of accumulated $\mathrm{NH}_{3}$ ions from photorespiration in photosynthesizing leaves and protein degradation in senescing leaves (Kwinta and Bielawski, 1998; Lasa et al., 2002; Skopelitis et al., 2007).

Information on the effects of low $\mathrm{N}$ supply on organic $\mathrm{N}$ metabolism involving GS and GDH in turfgrass is limited, particularly differential responses in growing leaves and senescing leaves to $\mathrm{N}$ deficiency. In red fescue (Festuca rubra) and seaside alkaligrass (Puccinellia maritime) found in a salt marsh, GS2 of the chloroplasts was dominant over GS1, comprising $70 \%$ to $80 \%$ of the total leaf GS activity (McNally et al., 1983). The GS and GDH activities in roots, stubble, or leaves of perennial ryegrass did not change significantly 2 weeks after clipping (Boucaud and Bigot, 1989). In a study on the effects of a fungal endophyte on $\mathrm{N}$ accumulation and metabolism in tall fescue (Festuca arundinacea), Lyons et al. (1990) found that total leaf GS activity expressed on a fresh weight basis was greater at high $\mathrm{N}$ supply than at low $\mathrm{N}$ supply, and endophyte-infected plants had greater leaf GS activity than the non-infected plants. Faure et al. (1998) found that perennial ryegrass colonized by an arbuscular mycorrhizal fungus had greater leaf GS activity than control plants, but this difference was not observed in roots. They also found that Gln was the main sink for nitrate-N immediately after nitrate was supplied to the roots. The nature of the activity of GS and GDH in growing leaves compared with senescing leaves under $\mathrm{N}$ deficiency has not yet been elucidated.

The objective of this study was to examine the effects of $\mathrm{N}$ deficiency on GS and GDH activities as well as AA and soluble protein contents in young and old leaves and roots of creeping bentgrass. This information will help us better understand the mechanisms of efficient $\mathrm{N}$ use in turfgrass given that these enzymes are critical in the assimilation of $\mathrm{NH}_{3}$ into AAs and in the detoxification of accumulated $\mathrm{NH}_{3}$ from nitrate reduction, photorespiration, protein degradation, and $\mathrm{AA}$ catabolism. The information may also benefit molecular research on $\mathrm{N}$ use efficiency because manipulation of GS and GDH genes affected root growth and productivity in other crops (Miflin and Habash, 2002).

\section{Materials and Methods}

Plant materials and nitrogen treatMENTS. Creeping bentgrass (cv. Penncross) was obtained from the Rutgers University research field in New Brunswick, NJ, and planted in $15-\mathrm{cm}$-diameter pots filled with fine sand. These pots of grass were grown in a greenhouse for 2 months (Feb. and Mar. 2010), watered daily, fertilized with a diluted $36 \mathrm{~N}-2.6 \mathrm{P}-5 \mathrm{~K}$ fertilizer, and clipped to a $1-\mathrm{cm}$ height weekly. On the last clipping in the greenhouse, the pots of grass were then moved to a reach-in growth chamber and allowed to acclimate for 2 weeks. The environment in the growth chamber was maintained at day/night temperatures of $20 / 15^{\circ} \mathrm{C}$, a photoperiod of $14 \mathrm{~h}$ with $500 \mu \mathrm{mol} \cdot \mathrm{m}^{-2} \cdot \mathrm{s}^{-1}$ photosynthetic photon flux, and $70 \%$ relative humidity. Each pot of grass was watered daily with $200 \mathrm{~mL}$ half-strength Hoagland's nutrient solution that contained $6.0 \mathrm{~mm}$ nitrate-N (Hoagland and Arnon, 1950). The complete composition was as follows: $0.92 \mathrm{~mm} \mathrm{KNO}_{3}, 2.56 \mathrm{~mm} \mathrm{Ca}\left(\mathrm{NO}_{3}\right)_{2} \cdot 4 \mathrm{H}_{2} \mathrm{O}, 0.6 \mathrm{~mm}$ $\mathrm{KH}_{2} \mathrm{PO}_{4}, 0.3 \mathrm{~mm} \mathrm{~K} \mathrm{SO}_{4}, 0.96 \mathrm{~mm} \mathrm{MgSO} \cdot 7 \mathrm{H}_{2} \mathrm{O}, 47.28 \mu \mathrm{M}$ $\mathrm{Fe}\left(\right.$ EDTA)Na, $11.22 \mu \mathrm{M} \mathrm{MnCl}_{2} \cdot 4 \mathrm{H}_{2} \mathrm{O}, 22.46 \mu \mathrm{M} \mathrm{H}_{3} \mathrm{BO}_{3}, 0.48$ $\mu \mathrm{M} \mathrm{CuSO} \mathrm{Cu}_{4} \cdot 5 \mathrm{H}_{2} \mathrm{O}, 14.18 \mu \mathrm{M} \mathrm{ZnSO} \cdot 7 \mathrm{H}_{2} \mathrm{O}$, and $0.08 \mu \mathrm{M}$ $\mathrm{Na}_{6} \mathrm{Mo}_{7} \mathrm{O}_{24} \cdot 4 \mathrm{H}_{2} \mathrm{O}$.

At the end of the 14-d acclimation period (15 Apr. 2010), four pots of grass were randomly selected and continued to receive the half-strength complete nutrient solution with $6 \mathrm{~mm}$ nitrate- $\mathrm{N}(+\mathrm{N}$ treatment) and another four randomly selected pots received the half-strength Hoagland's solution without any $\mathrm{N}$ (-N treatment), in which $\mathrm{KNO}_{3}$ was replaced with $\mathrm{K}_{2} \mathrm{SO}_{4}$ and $\mathrm{Ca}\left(\mathrm{NO}_{3}\right)_{2} \cdot 4 \mathrm{H}_{2} \mathrm{O}$ was replaced with $\mathrm{CaCl}_{2}$. Withholding $\mathrm{N}$ application $(-\mathrm{N})$ allowed for plants to develop $\mathrm{N}$ deficiency. These two treatments were made with $200 \mathrm{~mL}$ applied to each pot once every other day for 2 weeks and then daily for 2 weeks more because the $+\mathrm{N}$ plants had grown bigger and required more nutrient solution. All eight pots were randomly arranged in the growth chamber and each of the two $\mathrm{N}$ treatments had four replicate pots.

Leaves were sampled at 14, 21, and $28 \mathrm{~d}$ after initiation of the two $\mathrm{N}$ treatments. On the same stolon, the upper leaves are
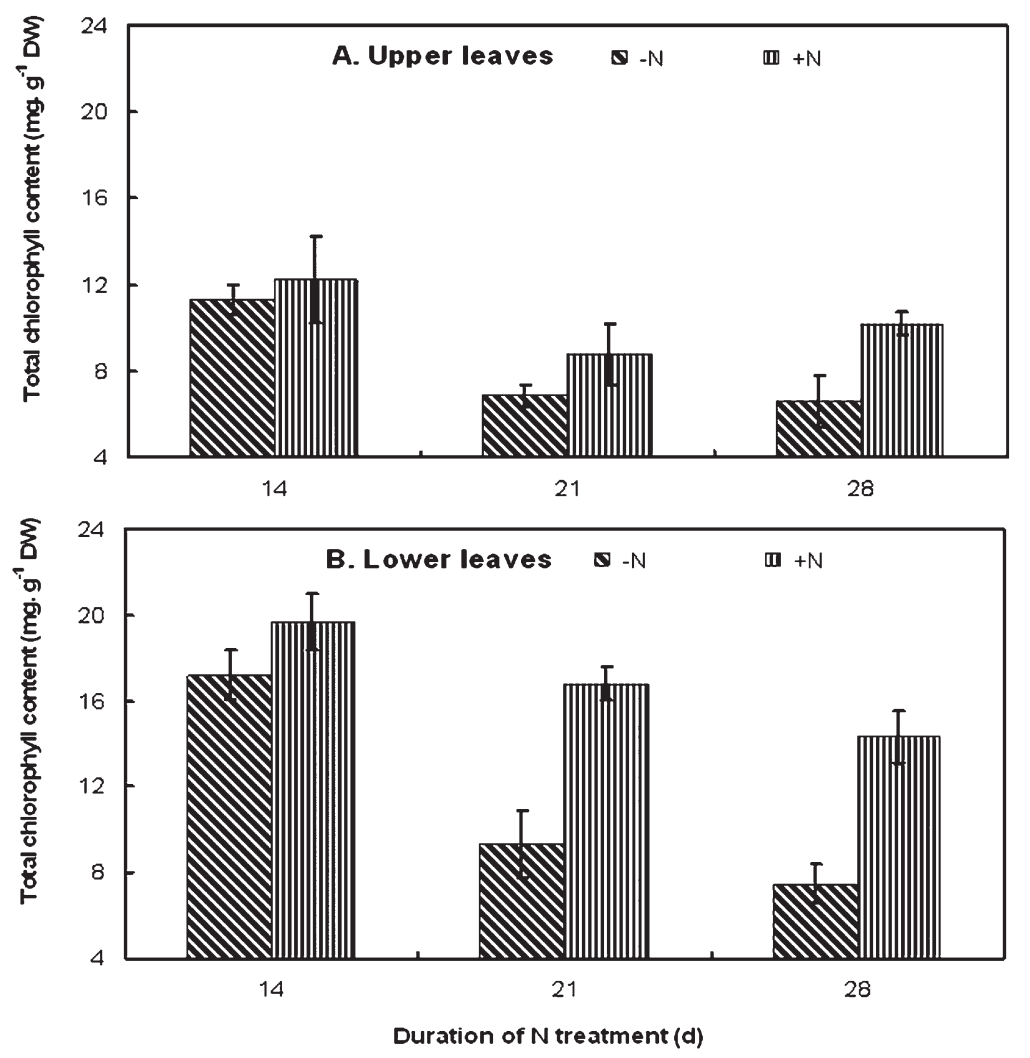

Fig. 1. Effects of nitrogen (N) deficiency on total chlorophyll content of the upper $(\mathbf{A})$ and the lower $(\mathbf{B})$ leaves of creeping bentgrass. Plants were treated with a nutrient solution containing zero $N(-N)$ or 6 mm nitrate $(+\mathrm{N})$ for the number of days indicated. A bar represents the mean of four replications and the vertical line on top of the bar represents the SD. Fisher's one-way multiple comparisons showed that any two means outside the ranges of their SD were significant at $P<0.05$. 
younger than the lower leaves because of the sequential leaf formation, maturation, and senescence. The leaf blades of the upper and the lower leaves were separated for dry weight (DW) and Chl content determinations and enzyme activity assays. Roots were sampled only at $28 \mathrm{~d}$ after initiation of the two $\mathrm{N}$ treatments and root samples were only taken from plants whose leaves were not sampled previously. Immediately after each sampling, the subsamples for AA, SP, GS, and GDH assays were placed in liquid $\mathrm{N}$ and then stored at $-80{ }^{\circ} \mathrm{C}$ until extraction.

ANALYSIS OF CHLOROPHYLL CONTENT, AMINO ACID, AND SOLUBLE PROTEIN CONTENT. The subsamples for DW determination were immediately weighed and placed in an oven at $70{ }^{\circ} \mathrm{C}$ for $5 \mathrm{~d}$ before they were weighed again. The subsamples for $\mathrm{Chl}$ content determination were immediately immersed in dimethyl sulfoxide (DMSO) in a ratio of $\approx 1.0 \mathrm{~g}$ fresh leaves to $50 \mathrm{~mL}$ of DMSO. The extraction was at room temperature and in complete darkness and lasted for $5 \mathrm{~d}$, at which point the leaves were all white. After 1:10 dilution with DMSO, the absorbance of extracted Chl was determined with a spectrophotometer (Genesys 2; Spectronic Instruments, Rochester, NY) at 663 and $645 \mathrm{~nm}$, and the total Chl $(\mathrm{a}+\mathrm{b})$ concentration in the extract was calculated according to the equation: concentration of $\mathrm{Chl}\left(\mathrm{mg} \cdot \mathrm{L}^{-1}\right)=20.2 \times$ absorbance at $645 \mathrm{~nm}+8.02 \times$ absorbance at $663 \mathrm{~nm}$ (Arnon, 1949). Tissue Chl content was expressed as milligrams per gram DW and calculated from the Chl concentration, the fresh weight used for the extraction, and the dry/fresh weight ratio of the corresponding sample.

Extraction for GS and GDH was based on methods used by Debouba et al. (2006), Faure et al. (1998), and Lu et al. (2005) and extraction for AA and SP was based on Caputo et al. (2009) with modifications. Samples frozen at $-80^{\circ} \mathrm{C}$ were ground in liquid $\mathrm{N}$ with a chilled mortar and pestle and then in a $4{ }^{\circ} \mathrm{C}$ extraction buffer. The buffer contained $50 \mathrm{~mm}$ Tris base adjusted to $\mathrm{pH} 7.5$ with $\mathrm{HCl}$, $1 \mathrm{~mm}$ ethylene diaminetetraacetic acid disodium salt, $1 \mathrm{~mm}$ phenylmethylsulfonyl fluoride, $1 \mathrm{~mm}$ dithiothreitol, $1 \% \mathrm{w} / \mathrm{v}$ polyvinylpyrrolidone, and $10 \mathrm{~mm} \mathrm{MgCl}_{2}$. The homogenate was centrifuged at $10,000 \mathrm{~g}_{\mathrm{n}}$ for $15 \mathrm{~min}$ and the supernatant was used as an extract for AA and SP concentration determinations as well as a crude enzyme extract for GS and GDH activity assays. All extraction steps were performed at 2 to $4{ }^{\circ} \mathrm{C}$ and the extract was used immediately for AA and SP concentration determinations and GS and GDH activity assays.

The AA concentration in the extract was determined using a ninhydrin method modified after Sun et al. (2006) and Yokohama and Kiramatsu (2003). Standard solutions of Glu were prepared in the extraction buffer described previously. A $1 \% \mathrm{w} / \mathrm{v}$ ninhydrin stock solution was prepared in DMSO that contained $0.025 \% \mathrm{w} / \mathrm{v}$ ascorbic acid. A working ninhydrin solution was prepared immediately before use by adding two parts of $4 \mathrm{M}$ sodium acetate buffer ( $\mathrm{pH}$ 5.5) to one part of the $1 \%$ ninhydrin stock solution. A $100-\mu \mathrm{L}$ aliquot of the extract or the standard Glu $P<0.05$. solution was added to $2.9 \mathrm{~mL}$ of the working ninhydrin solution in a heat-resistant tube, which was capped and heated at $100{ }^{\circ} \mathrm{C}$ for $15 \mathrm{~min}$. After being cooled in an ice bath for $10 \mathrm{~min}$, the purple-colored solution was diluted with $50 \%$ ethanol in a ratio of 1:4 and absorbance was read at $570 \mathrm{~nm}$ within $1 \mathrm{~h}$ of dilution. The AA concentration in the extract was calculated from the standard curve and then converted to tissue AA content expressed as micromoles per gram of tissues.

Protein concentration in the extract was determined using the dye-binding assay based on the method of Bradford (1976). The dye reagent contained $0.01 \% \mathrm{w} / \mathrm{v}$ Commassie Brilliant Blue $\mathrm{G}, 4.7 \% \mathrm{v} / \mathrm{v}$ ethanol, and $8.5 \% \mathrm{v} / \mathrm{v}$ phosphoric acid. Standard protein solutions of bovine serum albumin were prepared in the extraction buffer described previously. A $20-\mu \mathrm{L}$ aliquot of the extract or a standard protein solution was added to $1200 \mu \mathrm{L}$ of the dye reagent and the absorbance was read at $595 \mathrm{~nm}$ within $1 \mathrm{~h}$ of mixing. The protein concentration in the extract was calculated from the standard curve and was then converted to tissue SP content expressed as milligram per gram DW.

Assays of Glutamine SYNThetase AND GLUTAMate DeHYDROGENASE ACTIVITIES. Two methods of GS activity assay have been reported in the literature, one for the biosynthetic activity (Jin et al., 2007; Lyons et al., 1990; Machado et al., 2001; Rhodes et al., 1975) and the other for the transferase activity of
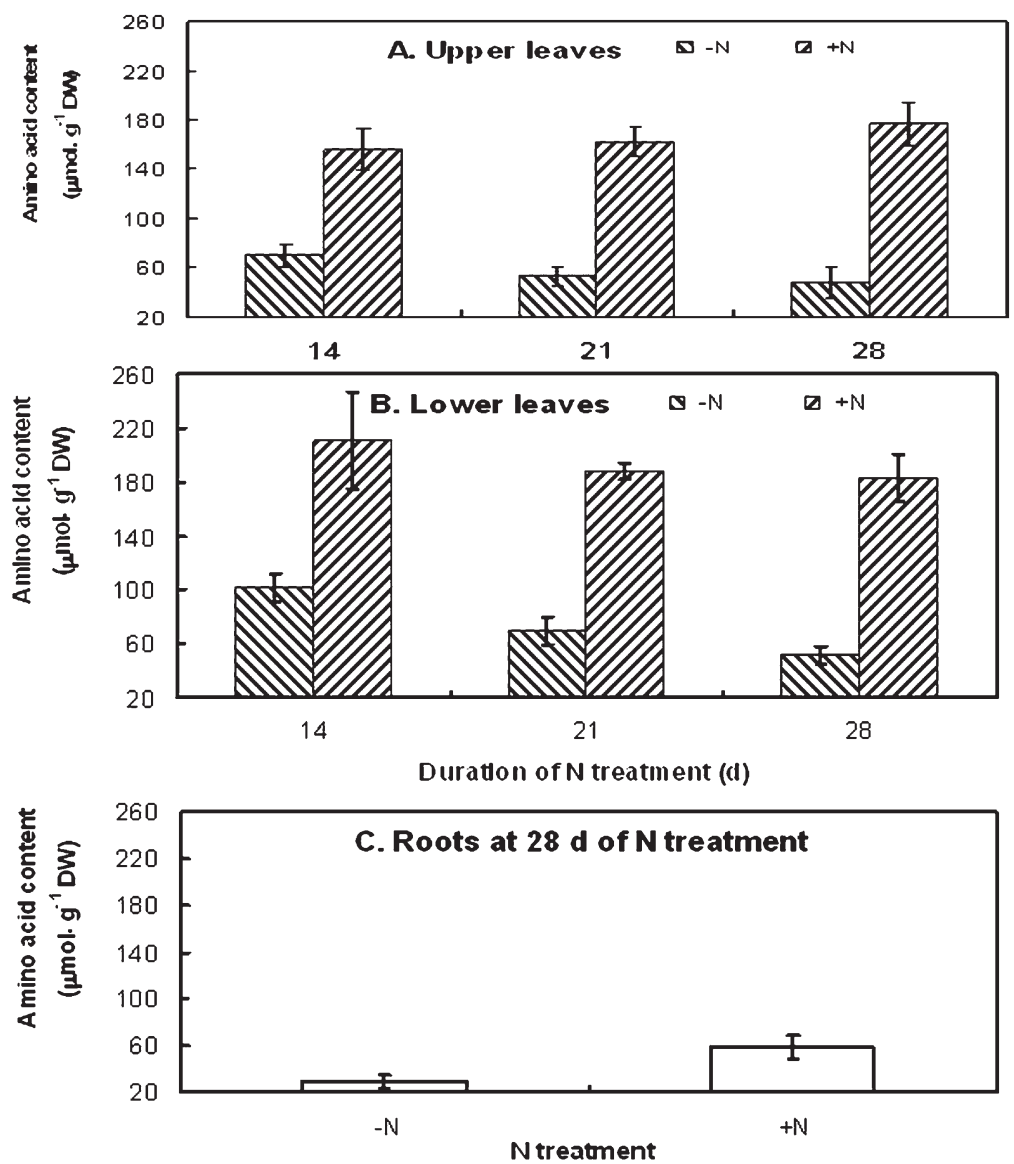

Fig. 2. Effects of nitrogen $(\mathrm{N})$ deficiency on amino acid content of the upper leaves (A), the lower leaves $(\mathbf{B})$, and roots $(\mathbf{C})$ of creeping bentgrass. Plants were treated with a nutrient solution containing zero $\mathrm{N}(-\mathrm{N})$ or $6 \mathrm{~mm}$ nitrate $(+\mathrm{N})$ for the number of days indicated. A bar represents the mean of four replications and the vertical line on top of the bar represents the SD. Fisher's one-way multiple comparisons showed that any two means outside the ranges of their SD were significant at 
GS (Hayakawa et al., 1990; Machado et al., 2001; Rhodes et al., 1975; Teixeira and Fidalgo, 2009). Both methods use hydroxylamine as a substrate and produce glutamyl hydroxamate, which reacts with a ferric chloride reagent to produce a pink solution. The present study used both methods with modifications. For the GS biosynthetic activity assay, the reaction mixture contained $100 \mathrm{~mm}$ imidazole, $100 \mathrm{~mm}$ Glu, $20 \mathrm{~mm}$ hydroxylamine, $10 \mathrm{~mm}$ ATP, and $50 \mathrm{~mm} \mathrm{MgSO}_{4}$ with a final $\mathrm{pH}$ of 7.5. For the GS transferase activity assay, the reaction mixture contained $100 \mathrm{~mm}$ imidazole, $60 \mathrm{~mm}$ Gln, $20 \mathrm{~mm}$ hydroxylamine, $2 \mathrm{~mm}$ adenosine 5'-diphosphate (ADP), $4 \mathrm{~mm}$ $\mathrm{MnCl}_{4}$, and $30 \mathrm{~mm} \mathrm{Na}_{2} \mathrm{HAsO}_{4}$ with a final $\mathrm{pH}$ of 7.5. The reaction was started by adding $100 \mu \mathrm{L}$ of the enzyme extract to $900 \mu \mathrm{L}$ of the reaction mixture, continued at $30^{\circ} \mathrm{C}$ in a water bath shaker for $20 \mathrm{~min}$, and then stopped by adding $400 \mu \mathrm{L}$ of a ferric chloride reagent containing $0.37 \mathrm{M} \mathrm{FeCl}_{3}$ and $0.2 \mathrm{M}$ trichloroacetic acid in $0.5 \mathrm{M} \mathrm{HCl}$. To obtain the baseline for each sample, the enzyme extract was added to the reaction mixture and the reaction was immediately stopped by adding the ferric chloride reagent without a 20 -min incubation period. The reaction solution was centrifuged to remove any precipitate and the absorbance of the supernatant was read at $540 \mathrm{~nm}$. Separate standard curves for the biosynthetic and transferase activities were obtained using known concentrations of glutamyl hydroxamate in the respective reaction mixtures without the enzyme extract. The activities were calculated from these curves and expressed as micromoles of product formed per hour per milligram protein.

The $\mathrm{NAD}^{+}$-dependent deamination and NADH-dependent amination activities of GDH were assayed by determining the concentration change of the coenzyme NADH in the reaction solution (Kumar et al., 2002; Kwinta et al., 2002; Restivo, 2004; Skopelitis et al., 2007) with modifications. Because GDH uses NAD ${ }^{+} / \mathrm{NADH}$ preferentially over $\mathrm{NADP}^{+} / \mathrm{NADPH}$ (Kwinta and Bielawski, 1998 ), only $\mathrm{NAD}^{+} / \mathrm{NADH}$ was used as a coenzyme for GDH in the present study. The reaction mixture for $\mathrm{NAD}^{+}$-GDH deamination activity assay contained $100 \mathrm{~mm}$ Tris base, $50 \mathrm{~mm}$ Glu, $0.5 \mathrm{~mm} \mathrm{NAD}^{+}$, and $1 \mathrm{~mm}$ $\mathrm{CaCl}_{2}$ with a $\mathrm{pH}$ of 9.0. The reaction mixture for NADH-GDH amination activity assay contained $100 \mathrm{~mm}$ Tris base, $100 \mathrm{~mm}$ $\left(\mathrm{NH}_{4}\right)_{2} \mathrm{SO}_{4}, 20 \mathrm{~mm}$ 2-oxoglutarate, $0.1 \mathrm{~mm}$ $\mathrm{NADH}$, and $1 \mathrm{~mm} \mathrm{CaCl}_{2}$ with a pH of 8.0. The reaction was started by adding $20 \mu \mathrm{L}$ of the enzyme extract to $1000 \mu \mathrm{L}$ of the reaction mixture. After a 10-min pre-incubation at $30^{\circ} \mathrm{C}$, the absorbance of NADH in the reaction solution was read at $340 \mathrm{~nm}$ and again on completion of an additional 30-min incubation at $30^{\circ} \mathrm{C}$. Separate standard curves were obtained using known concentrations of $\mathrm{NADH}$ in a $\mathrm{NAD}^{+}-\mathrm{GDH}$ reaction mixture or NADH-GDH reaction mixture without the enzyme extract. The rate of $\mathrm{NAD}^{+}$reduction or NADH oxidation was calculated from these standard curves. The $\mathrm{NAD}^{+}-\mathrm{GDH}$ or $P<0.05$.
NADH-GDH activity was expressed as micromoles of NADH produced or used, respectively, per hour per milligram protein.

Statistical analysis. Statistical analyses were performed using Minitab 16 for Windows (Minitab, State College, PA) and data reported were means of four replicate samples along with SDS. One-way analysis of variance was used to evaluate whether significant difference existed at $P \leq 0.05$ between the $+\mathrm{N}$ and the $-\mathrm{N}$ treatments; among young leaves, old leaves, and roots; or among sampling dates. Where more than two means were compared, significant means were separated by the Fisher's one-way multiple comparison test at $95 \%$ or greater confidence levels.

\section{Results}

EFFECTS OF NITROGEN ON LEAF CHLOROPHYLL, AMINO ACID, AND SOLUBLE PROTEIN CONTENT. The $-\mathrm{N}$ treatment for $14 \mathrm{~d}$ did not decrease Chl content of the upper leaves compared with the $+\mathrm{N}$ treatment, but the difference between $-\mathrm{N}$ and $+\mathrm{N}$ treatments became greater at $21 \mathrm{~d}$ and more so at $28 \mathrm{~d}$ (Fig. 1A). In contrast, the $-\mathrm{N}$ treatment for $14 \mathrm{~d}$ decreased $\mathrm{Chl}$ content of the lower leaves compared with the $+\mathrm{N}$ treatment, and the difference between $-\mathrm{N}$ and $+\mathrm{N}$ treatments became much
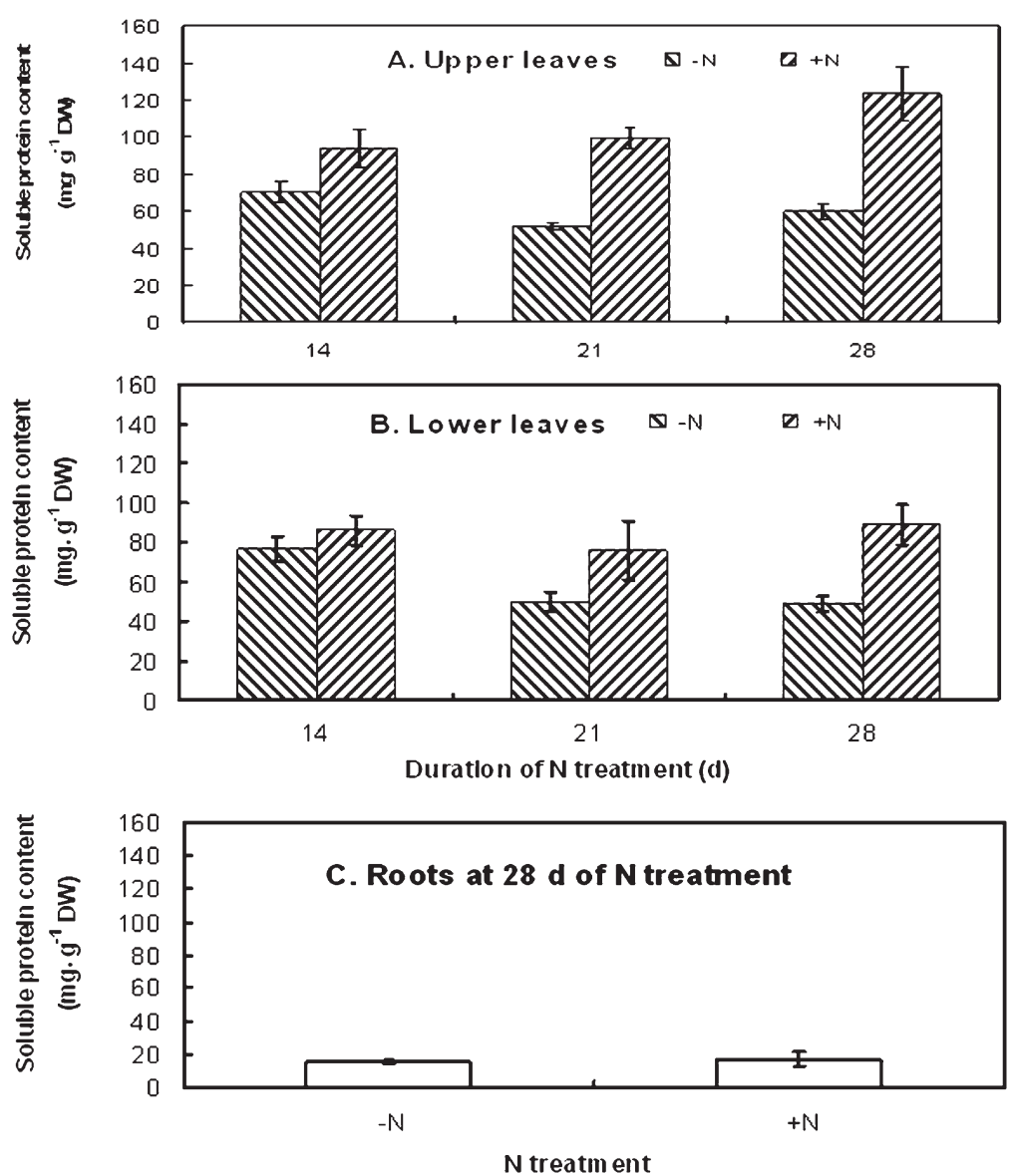

Fig. 3. Effects of nitrogen $(\mathrm{N})$ deficiency on soluble protein content of the upper leaves $(\mathbf{A})$, the lower leaves $(\mathbf{B})$, and roots $(\mathbf{C})$ of creeping bentgrass. Plants were treated with a nutrient solution containing zero $\mathrm{N}(-\mathrm{N})$ or $6 \mathrm{~mm}$ nitrate $(+\mathrm{N})$ for the number of days indicated. A bar represents the mean of four replications and the vertical line on top of the bar represents the SD. Fisher's one-way multiple comparisons showed that any two means outside the ranges of their SD were significant at 
greater at 21 and $28 \mathrm{~d}$ (Fig. 1B). In both treatments, decrease of $\mathrm{Chl}$ content with time was observed in the lower leaves, but this decrease was not sustained in the upper leaves. Within the same treatment at the same date, the lower leaves had higher $\mathrm{Chl}$ content than the upper leaves.

The $-\mathrm{N}$ treatment decreased AA content in the upper leaves, the lower leaves, and roots compared with the $+\mathrm{N}$ treatment (Fig. 2 ), and the difference in leaf AA content between $-\mathrm{N}$ and $+\mathrm{N}$ treatments was significant as early as $14 \mathrm{~d}$ of treatment regardless of leaf age (Fig. 2A-B). The AA content of the upper or the lower leaves in the $+\mathrm{N}$ treatment showed no decrease with time (Fig. 2A-B), but the AA content of the lower leaves in the $-\mathrm{N}$ treatment decreased with duration of treatment (Fig. 2B). Within the same treatment at 14 or $21 \mathrm{~d}$, the lower leaves had higher AA content than the upper leaves.

The $-\mathrm{N}$ treatment decreased SP content in the upper leaves at all three dates and in the lower leaves at 21 and $28 \mathrm{~d}$ of treatment compared with the same tissue in the $+\mathrm{N}$ treatment (Fig. 3A-B). The SP content of the upper and the lower leaves in the $-\mathrm{N}$ treatment decreased between 14 and $21 \mathrm{~d}$, but that of the $+\mathrm{N}$ treatment did not decrease with duration of $\mathrm{N}$ treatment (Fig. 3A-B). Within the same treatment at the same date, the SP content of the upper leaves was generally higher than that of the lower leaves, and the difference was larger in the $+\mathrm{N}$ treatment than in the $-\mathrm{N}$ treatment. Roots had the lowest SP content and showed no difference between the $-\mathrm{N}$ and $+\mathrm{N}$ treatments (Fig. 3C).

EFFECTS OF NITROGEN ON ACTIVITIES OF GLUTAMINE SYNTHETASE. The deprivation of N supply increased GS biosynthetic activity in the upper and the lower leaves but not in roots compared with the same tissue in the $+\mathrm{N}$ treatment (Fig. 4). In the upper leaves, this increase was observed at all three dates, and the magnitude of difference between $-\mathrm{N}$ and $+\mathrm{N}$ treatments became greater with time (Fig. 4A). In the lower leaves, the difference between $-\mathrm{N}$ and $+\mathrm{N}$ treatments was not observed at $14 \mathrm{~d}$ but increased with duration of $\mathrm{N}$ treatment (Fig. 4B). In the $-\mathrm{N}$ treatment, the GS biosynthetic activity of both the upper and the lower leaves increased dramatically from 14 to $21 \mathrm{~d}$ but not from 21 to $28 \mathrm{~d}$ (Fig. 4A-B). The upper and lower leaves within the same $\mathrm{N}$ treatment at the same date had similar biosynthetic activities. The roots had much higher activities than either the upper or the lower leaves on a protein basis (Fig. 4A-C) but showed no difference between $-\mathrm{N}$ and $+\mathrm{N}$ treatments.

The deprivation of $\mathrm{N}$ supply increased GS transferase activity in the upper and the lower leaves and roots (Fig. 5) compared with the same tissue in the $+\mathrm{N}$ treatment. In either the upper or the lower leaves, the difference between $-\mathrm{N}$ and $+\mathrm{N}$ treatments was smaller at $14 \mathrm{~d}$ than at 21 or $28 \mathrm{~d}$ (Fig. $5 \mathrm{~A}$ ). In the $-\mathrm{N}$ treatment, the GS transferase activity of both the upper and the lower leaves increased with duration of treatment (Fig. $5 \mathrm{~A}-\mathrm{B})$. Within the same treatment, the upper and the lower leaves had similar transferase activities. The roots had much higher activities than either the upper or the lower leaves and showed a significant difference between $-\mathrm{N}$ and $+\mathrm{N}$ treatments (Fig. 5C).

EFFECTS OF NITROGEN ON ACTIVITIES OF GLUTAMATE DEHYDROGENASE. In the upper leaves, deprivation of $\mathrm{N}$ supply for 14 to $28 \mathrm{~d}$ did not change the $\mathrm{NAD}^{+}$-dependent GDH deamination activity compared with the $+\mathrm{N}$ treatment (Fig. 6A). However, in the lower leaves, deprivation of $\mathrm{N}$ supply for 21 and $28 \mathrm{~d}$ increased $\mathrm{NAD}^{+}-\mathrm{GDH}$ activity (Fig. 6B). In contrast, root $\mathrm{NAD}^{+}-\mathrm{GDH}$ activity was lower at $28 \mathrm{~d}$ of $-\mathrm{N}$ treatment compared with the $+\mathrm{N}$ treatment (Fig. 6C). Within the $-\mathrm{N}$ treatment, the $\mathrm{NAD}^{+}-\mathrm{GDH}$ activity of the lower leaves increased with duration of treatment (Fig. 6B). Also within the $-\mathrm{N}$ treatment, the $\mathrm{NAD}^{+}-\mathrm{GDH}$ activity of the upper leaves was higher than that of the lower leaves at $14 \mathrm{~d}$, similar to that of lower leaves at $21 \mathrm{~d}$ and lower than that of the lower leaves at $28 \mathrm{~d}$ (compare Fig. 6A and 6B). Roots had the highest $\mathrm{NAD}^{+}$GDH activity (Fig. 6A-C).

In the upper leaves, deprivation of $\mathrm{N}$ supply for 14 to $28 \mathrm{~d}$ increased the NADH-dependent GDH amination activity when the three dates were combined compared with the $+\mathrm{N}$ treatment, but the difference between $-\mathrm{N}$ and $+\mathrm{N}$ treatments was not observed on any specific date (Fig. 7A). However, in the lower 

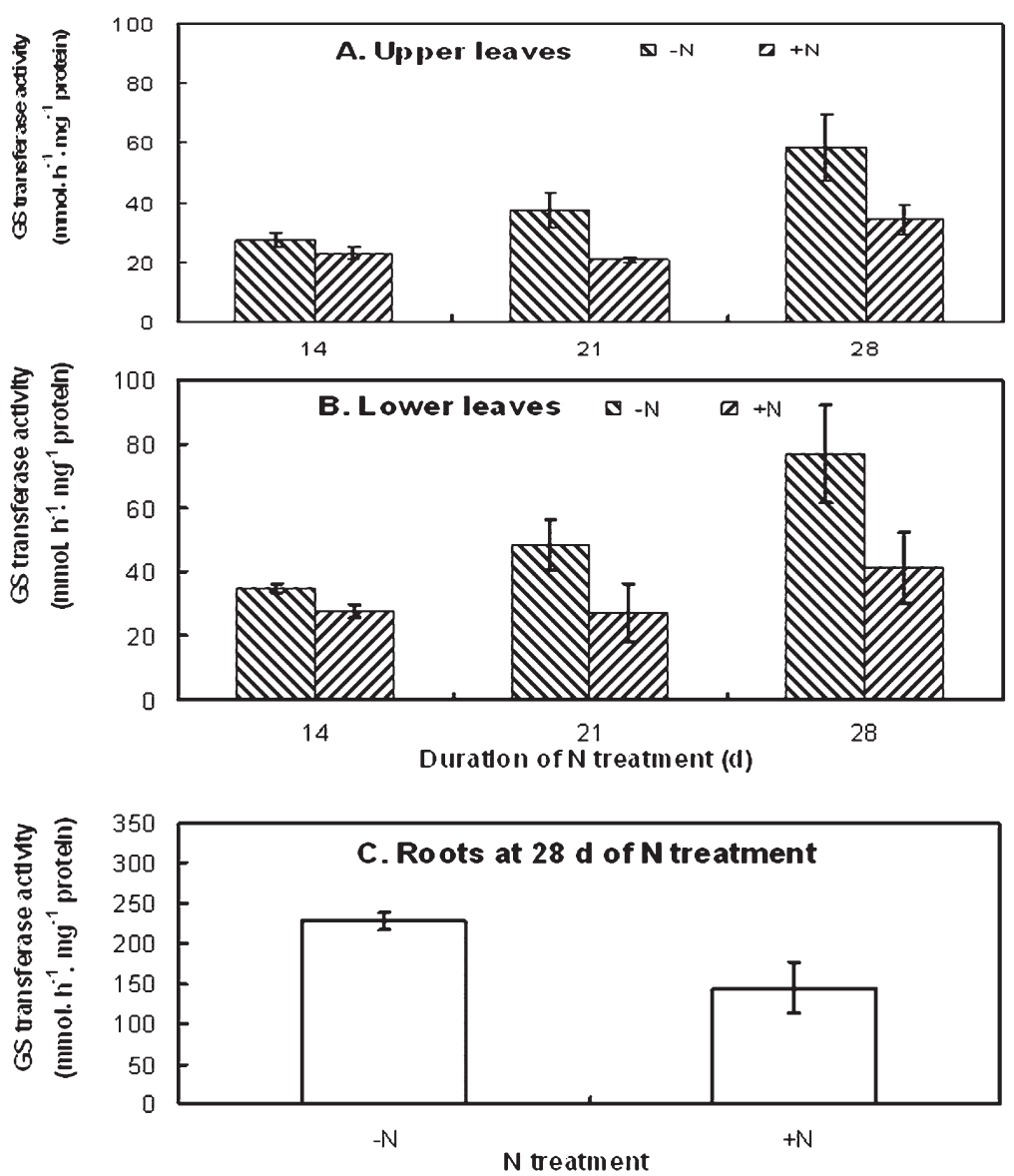

Fig. 5. Effects of nitrogen $(\mathrm{N})$ deficiency on glutamine synthetase transferase activity of the upper leaves (A), the lower leaves $(\mathbf{B})$, and roots $(\mathbf{C})$ of creeping bentgrass. Plants were treated with a nutrient solution containing zero $\mathrm{N}(-\mathrm{N})$ or $6 \mathrm{~mm}$ nitrate $(+\mathrm{N})$ for the number of days indicated. A bar represents the mean of four replications and the vertical line on top of the bar represents the SD. Fisher's one-way multiple comparisons showed that any two means outside the ranges of their SD were significant at $P<0.05$.

leaves, deprivation of $\mathrm{N}$ supply for 21 or $28 \mathrm{~d}$ increased NADHGDH activity (Fig. 7B). In contrast, root NADH-GDH activity showed no difference between $-\mathrm{N}$ and $+\mathrm{N}$ treatments at $28 \mathrm{~d}$ (Fig. 7C). In the $+\mathrm{N}$ treatment, NADH-GHD activity of the upper or the lower leaves was similar among the three dates, but in the $-\mathrm{N}$ treatment, the NADH-GDH activity of the lower leaves increased from 14 and $21 \mathrm{~d}$ (Fig. 7B). Within the same $\mathrm{N}$ treatment, the upper and the lower leaves had similar NADHGDH activity, but roots had higher activities than both the upper and the lower leaves (Fig. 7A-C).

\section{Discussion}

Chl content is one of the most commonly used indicators of leaf senescence (Lim et al., 2007). On the same stolon, the upper leaves are younger than the lower leaves because leaf formation, maturation, or senescence in creeping bentgrass is sequential. Despite younger age, the upper leaves differed in Chl content between the $\mathrm{N}$ treatments at 21 or $28 \mathrm{~d}$ (Fig. 1A). This may be because fewer new leaves could emerge in the $-\mathrm{N}$ plants than in the $+\mathrm{N}$ plants and the upper leaves of the $-\mathrm{N}$ plants would become older and lose more $\mathrm{Chl}$ than the upper leaves of the $+\mathrm{N}$ plants as the treatments were prolonged. In the lower leaves, natural senescence occurred even under sufficient
$\mathrm{N}$ supply as demonstrated by the decrease of Chl content over time (Fig. 1B). This is in agreement with the report in rice (Oryza sativa) that naturally senescing leaves lost Chl over time (Kamachi et al., 1991). Our results further showed that deprivation of $\mathrm{N}$ supply promoted this natural senescence in the lower leaves and further induced senescence in the upper leaves when $\mathrm{N}$ deficiency was prolonged. Therefore, proper $\mathrm{N}$ nutrition is important in attenuating natural senescence and preventing premature senescence.

During leaf senescence, AAs are produced from protein degradation and exported from senescing leaves to growing leaves (Liu et al., 2008). We observed that AA content in young and old leaves and in roots decreased as a result of $\mathrm{N}$ deficiency (Fig. 2), which is consistent with a report that $\mathrm{N}$ deprivation decreased AA content in perennial ryegrass roots (Louahlia et al., 2008). Free AAs were the predominant storage compounds of reserve $\mathrm{N}$ for the regrowth of the bushgrass (Calamagrostis epigejos) after defoliation (Kavanová and Gloser, 2005). This may also be true under $\mathrm{N}$ deficiency as indicated by the decreased AA levels under $\mathrm{N}$ deficiency in the present study. In addition, $\mathrm{SP}$ in the lower leaves may have provided additional reserve $\mathrm{N}$ for the growth of the upper leaves under prolonged $\mathrm{N}$ deficiency as indicated by decreased SP levels in the lower leaves in the later stage of $\mathrm{N}$ deprivation. Furthermore, SP levels in the roots did not decrease significantly under prolonged $\mathrm{N}$ deficiency, which may suggest that root SP was not a significant source of reserve $\mathrm{N}$ for the growth of the upper leaves within $28 \mathrm{~d}$ of N deprivation. Bowman (1993) and Ourry et al. (1990) showed that $\mathrm{N}$ deprivation resulted in the remobilization of total $\mathrm{N}$ or reduced $\mathrm{N}$ (total $\mathrm{N}$ excluding nitrate-N) from roots and stubble to the growing leaves after defoliation. Our results suggested that free AA pools in the older leaves may have been remobilized for the growth of younger leaves when $\mathrm{N}$ deficiency was mild and degradation of SPs in the older leaves may have followed when $\mathrm{N}$ deficiency was prolonged.

The enzyme GS plays an important role in $\mathrm{N}$ assimilation and remobilization during senescence (Bernard and Habash, 2009; Kamachi et al., 1991; Miflin and Habash, 2002). The ATPdependent GS biosynthetic activity combines Glu and $\mathrm{NH}_{3}$ from protein degradation to Gln, which was shown to be a predominant amide in perennial ryegrass phloem sap (Amiard et al., 2004). Alternatively, when ATP levels are low and ADP levels are high, the ADP-dependent GS transferase activity may convert Gln to Glu, which was also a major amino acid found in perennial ryegrass phloem sap (Amiard et al., 2004) and in rice leaf blades (Kamachi et al., 1991). Our results showed that the GS biosynthetic and transferase activities of the upper and the lower leaves expressed on a protein basis increased with prolonged $\mathrm{N}$ deficiency. These findings appeared inconsistent with previous reports on leaf GS activities expressed on a fresh weight basis. Boucaud and Bigot (1989) found no significant change over 

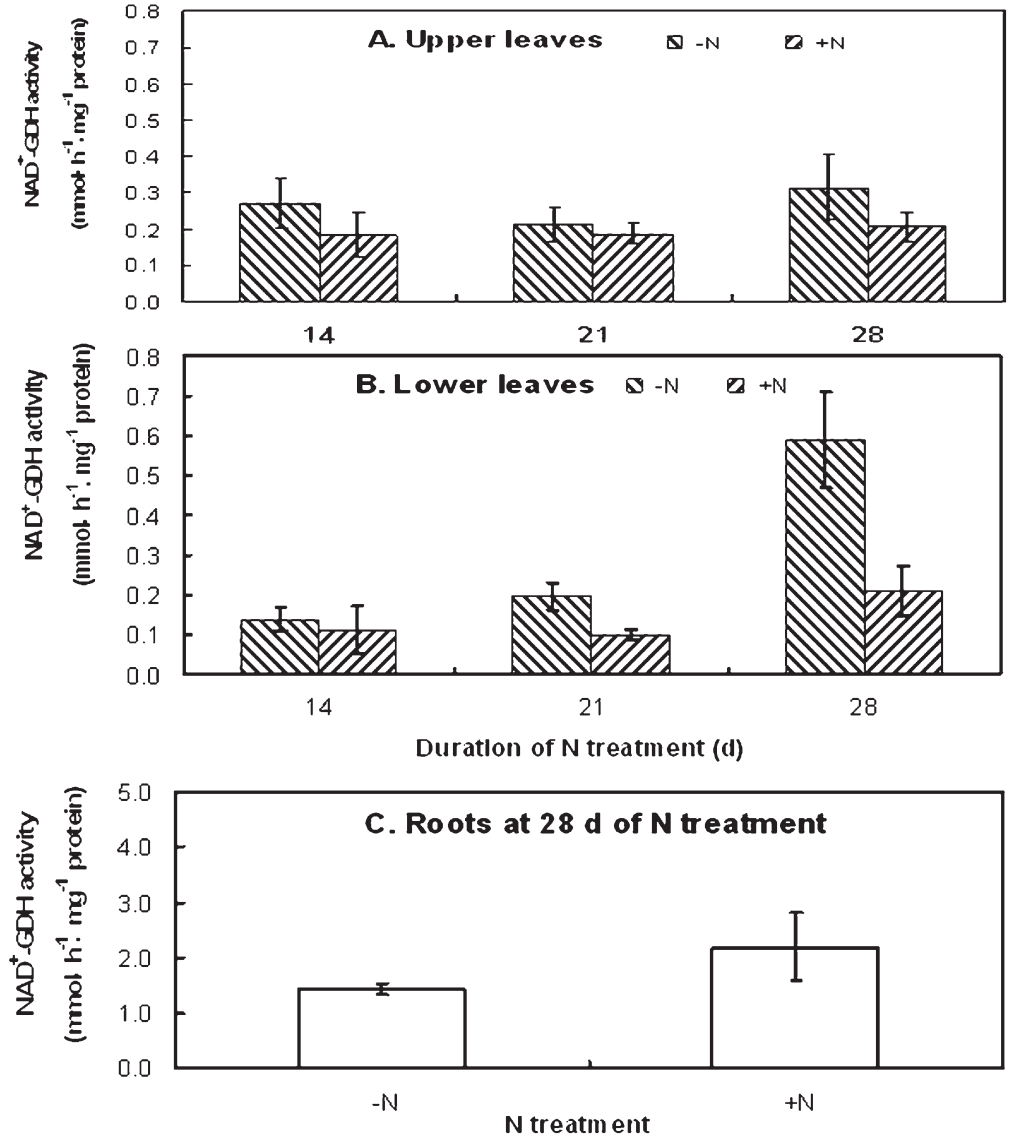

Fig. 6. Effects of $\mathrm{N}$ deficiency on $\mathrm{NAD}^{+}$-dependent glutamate dehydrogenase activity of the upper leaves (A), the lower leaves $(\mathbf{B})$, and roots $(\mathbf{C})$ of creeping bentgrass. Plants were treated with a nutrient solution containing zero nitrogen $(-\mathrm{N})$ or $6 \mathrm{~mm}$ nitrate $(+\mathrm{N})$ for the number of days indicated. A bar represents the mean of four replications and the vertical line on top of the bar represents the SD. Fisher's one-way multiple comparisons showed that any two means outside the ranges of their SD were significant at $P<0.05$.

time in perennial ryegrass leaf GS activity after defoliation. Lyons et al. (1990) found a lower leaf GS activity in tall fescue at a low N supply than at a high N supply. Kamachi et al. (1991) found a decrease of leaf GS activity during senescence of rice leaves and the decrease in leaf GS activity was mainly caused by a decrease of the GS2 polypeptide in the chloroplasts and that GS1 mRNA levels in the cytosol increased during natural senescence of rice leaves. Because GS2 of the leaves is located in the chloroplast (Lam et al., 1996), in which protein breakdown is the first step in protein $\mathrm{N}$ remobilization (Lim et al., 2007; Liu et al., 2008), GS2 may be degraded early during senescence. A more recent study found that the GS1 gene was upregulated in Arabidopsis thaliana leaves under severe N deficiency (Bi et al., 2007). Therefore, in senescing leaves, the GS activities may be primarily a result of the GS1 activities. In addition, when the plants were deprived of $\mathrm{N}$ supply for an extended period, $28 \mathrm{~d}$ in our study, the role of GS1 in assimilating $\mathrm{NH}_{3}$ from root uptake or nitrate reduction would be diminished. Furthermore, the role of GS1 in assimilating $\mathrm{NH}_{3}$ from photorespiration would also be minimal because photorespiration is repressed in N-deprived plants (Bi et al., 2007). Given all these reasons, the increase of the leaf GS activities during $\mathrm{N}$ deficiency-induced senescence in our study would be expected because of the increased role of leaf GS1 in assimilating $\mathrm{NH}_{3}$ from protein degradation in senescing leaves.
In the roots, our study showed that the GS transferase activity increased as a result of $\mathrm{N}$ deprivation for $28 \mathrm{~d}$, but this increase was not observed for the GS biosynthetic activity. In some previous studies, the GS activity was based either on the biosynthetic activity (Jin et al., 2007; Lyons et al., 1990) or on the transferase activity (Hayakawa et al., 1990; Teixeira and Fidalgo, 2009). In studies that assayed both activities of GS, differences between the two activities were observed. Rhodes et al. (1975) found that the GS in the fronds of Lemna minor had a higher biosynthetic activity than the transferase activity and did not show a consistent ratio of the two activities, although both activities were affected by Gln concentrations. They suggested that the GS regulation by GIn may involve a change in the ratio. Machado et al. (2001) found that maize (Zea mays) leaf GS had a higher transferase activity than the biosynthetic activity, and cultivars with different yield potentials differed in their transferase activities more than they did in their biosynthetic activities across several combinations of nitrate- $\mathrm{N}$ and $\mathrm{NH}_{3}-\mathrm{N}$. In assaying Escherichia coli GS activities, Shapiro and Stadtman (1970) found that the transferase activity was less subject to interference by other enzymes. In addition, the biosynthetic activity is ATP-dependent and the transferase activity is ADP-dependent. In the present study, the GS transferase activity in the roots was 10 to 20 times higher than the biosynthetic activity and the reasons could be a combination of the factors discussed (i.e., Gln and ATP levels), interference by other enzymes, and inherent difference in creeping bentgrass roots. Our results may suggest that the GS transferase activity was more sensitive in detecting the differences in the roots and the increased root GS transferase activity under $28-\mathrm{d} N$ deficiency could be a result of the upregulated GS1 gene in the cytosol of the roots as suggested for the leaves.

The $\mathrm{NAD}^{+}-\mathrm{GDH}$ deamination activity converts Glu to 2-oxoglutarate, especially when carbohydrates are limited, with 2-oxoglutarate entering the tricarboxylic acid cycle for energy production (Miflin and Habash, 2002). The NADH-GDH amination activity combines 2-oxoglutarate and $\mathrm{NH}_{3}$ to produce Glu without ATP, but in the chloroplasts of growing or mature leaves, the main route of Glu production is the ATPdependent GS-GOGAT pathway (Dubois et al., 2003). The GDH amination activity may be induced by high concentrations of $\mathrm{NH}_{3}$ and could reduce $\mathrm{NH}_{3}$ toxicity (Lasa et al., 2002). In the present study, we found that the amination activity was five to 10 times higher than the deamination activity (Figs. 6 and 7). This is in agreement with previous reports (Skopelitis et al., 2007; Turano et al., 1996), in which the amination activity was also found to be higher than the deamination activity. In addition, we also found that both activities of GDH increased in senescing leaves of creeping bentgrass when $\mathrm{N}$ deficiency became severe. Given that senescence-associated cell death did not occur uniformly within a leaf (Lim et al., 2007), GDH could be involved 

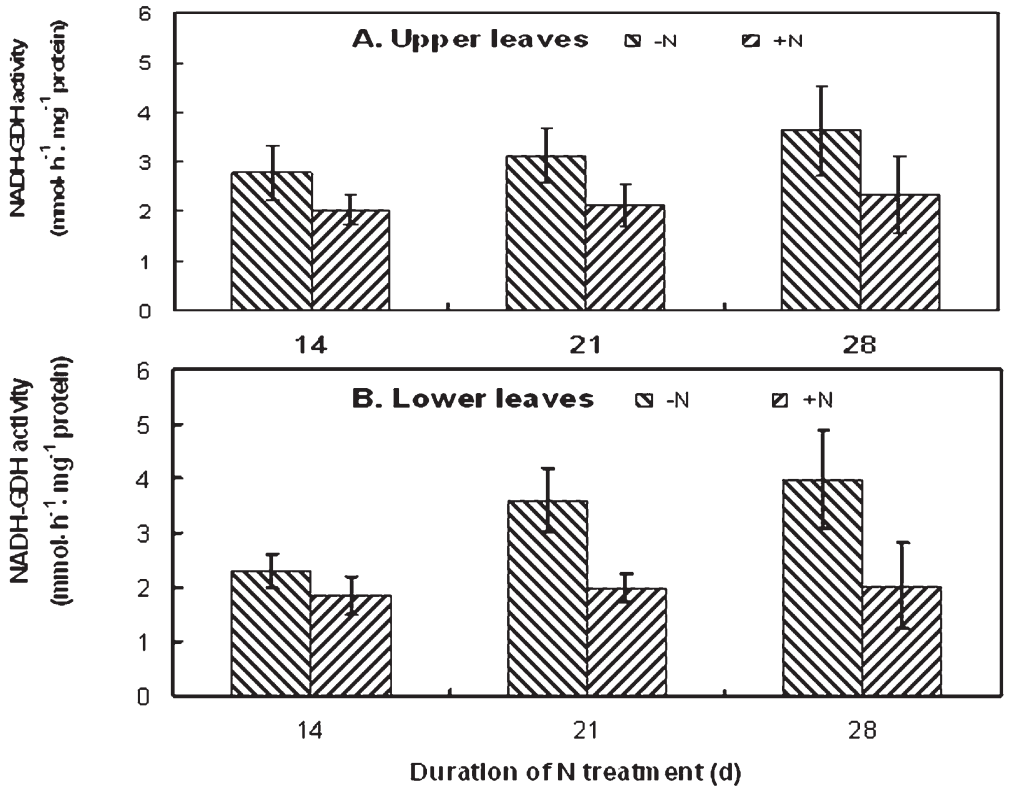

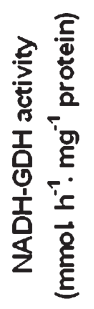

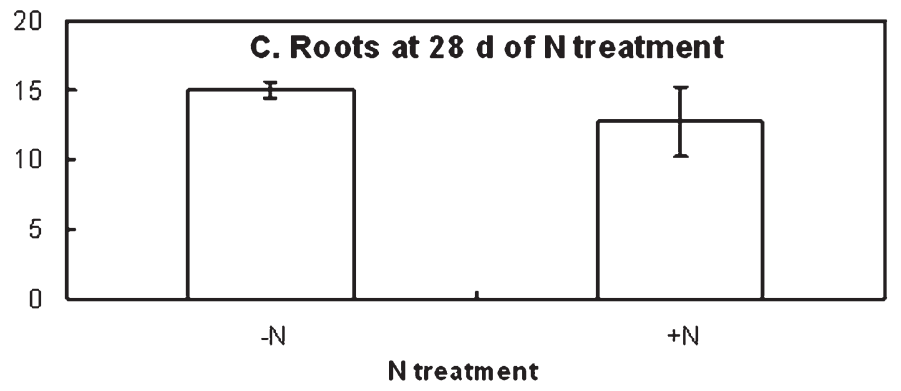

Fig. 7. Effects of nitrogen $(\mathrm{N})$ deficiency on NADH-dependent glutamate dehydrogenase activity of the upper leaves (A), the lower leaves $(\mathbf{B})$, and roots $(\mathbf{C})$ of creeping bentgrass. Plants were treated with a nutrient solution containing zero $\mathrm{N}(-\mathrm{N})$ or $6 \mathrm{~mm}$ nitrate $(+\mathrm{N})$ for the number of days indicated. A bar represents the mean of four replications and the vertical line on top of the bar represents the SD. Fisher's one-way multiple comparisons showed that any two means outside the ranges of their SD were significant at $P<0.05$.

in producing Glu, 2-oxoglutarate, or both depending on particular needs of the cells in different parts of the senescing leaf. Furthermore, samples of the lower leaves inevitably included leaves at different stages of senescence with various $\mathrm{C} / \mathrm{N}$ ratios and thus could result in different ratios of deamination to amination activities (Miflin and Habash, 2002). Our results demonstrated that severe $\mathrm{N}$ deficiency increased the GDH activities in senescing leaves, which is consistent with the stress-responsive nature of the enzyme (Restivo, 2004).

In the roots, the $\mathrm{NAD}^{+}$-dependent GDH deamination activity decreased as a result of 28-d N deficiency in comparison with the $+\mathrm{N}$ treatment. Previous studies have shown that $\mathrm{N}$ deficiency stimulated export of assimilates to roots of darnel (Lolium temulentum) (Powell and Ryle, 1978) and increased root watersoluble carbohydrate of perennial ryegrass (Louahlia et al., 2008). The lower deamination activity observed in roots of $\mathrm{N}$-deficient plants in the present study may suggest that a higher level of carbohydrate in the roots of $-\mathrm{N}$ plants may suppress the deamination activity, whereas a lower level of carbohydrate in the roots of $+\mathrm{N}$ plants may stimulate the deamination activity. In addition, the GDH amination activity of the roots did not exhibit any difference between the two $\mathrm{N}$ treatments. This result could be expected because 1) roots had low levels of soluble proteins; 2) $\mathrm{NH}_{3}$ release from protein degradation would be low; and 3) the role of GDH amination activity in $\mathrm{NH}_{3}$ detoxification would be diminished.

In summary, $\mathrm{N}$ deficiency accelerated leaf senescence, as exhibited by the decline in $\mathrm{Chl}, \mathrm{AA}$, and SP content in leaves subjected to low $\mathrm{N}$ treatment. Both GS biosynthetic and transferase activities and both GDH deamination and amination activities increased under N-deficient conditions, whereas in the roots, prolonged $\mathrm{N}$ deficiency increased GS transferase activity and GDH deamination activity. Our results suggest that these enzymes may be involved in $\mathrm{N}$ remobilization and $\mathrm{C} / \mathrm{N}$ balance of senescing tissues and that the changes in these enzymes may be adaptive responses to prolonged $\mathrm{N}$ deficiency. Further studies on these enzymes and the genes coding for them may have potential for improving $\mathrm{N}$ use efficiency of creeping bentgrass.

\section{Literature Cited}

Amiard, V., A. Morvan-Bertrand, J.B. Cliquet, J.P. Billard, C. Huault, J.P. Sandström, and M.P. Prudhomme. 2004. Carbohydrate and amino acid composition in phloem sap of Lolium perenne L. before and after defoliation. Can. J. Bot. 82:1594-1601.

Arnon, D.I. 1949. Copper enzymes in isolated chloroplasts. Polyphenoloxidase in Beta vulgaris. Plant Physiol. 24:1-13.

Bernard, S.M. and D.Z. Habash. 2009. The importance of cytosolic glutamine synthetase in nitrogen assimilation and recycling. New Phytol. 182:608-620.

Bi, Y., R. Wang, T. Zhu, and S.J. Rothstein. 2007. Global transcription profiling reveals differential responses to chronic nitrogen stress and putative nitrogen regulatory components in Arabidopsis. BMC Genomics 8:281-298.

Boucaud, J. and J. Bigot. 1989. Changes in the activities of nitrogen assimilation enzymes of Lolium perenne L. during regrowth after cutting. Plant Soil 114:121-125.

Bowman, D.C. 1993. The effects of nitrogen deficiency on tissue $\mathrm{NO}_{3}$, reduced $\mathrm{N}$, soluble carbohydrates, and uptake of $\mathrm{NO}_{3}{ }^{-}$and $\mathrm{NH}_{4}{ }^{+}$by perennial ryegrass. Intl. Turfgrass Soc. Res. J. 7:664-672.

Bradford, M.M. 1976. A rapid and sensitive method for the quantitative determination of microgram quantities of protein utilizing the principle of protein-dye binding. Ann. Biochem. 72:248-254.

Caputo, C., M.V. Criado, I.N. Roberts, M.A. Gelso, and A.J. Barneix. 2009. Regulation of glutamine synthetase 1 and amino acids transport in the phloem of young wheat plants. Plant Physiol. Biochem. 47:335-342.

Debouba, M., H. Gouia, A. Suzuki, and M.H. Ghorbel. 2006. NaCl stress effects on enzymes involved in nitrogen assimilation pathway in tomato Lycopersicon esculentum seedlings. J. Plant Physiol. 163:1247-1258.

Dubois, F., T. Tercé-Laforgue, M.B. Gonzalez-Moro, J.M. Estavillo, R. Sangwan, A. Gallais, and B. Hirel. 2003. Glutamate dehydrogenase in plants: Is there a new story for an old enzyme? Plant Physiol. Biochem. 41:565-576.

Faure, S., J.B. Cliquet, G. Thephany, and J. Boucaud. 1998. Nitrogen assimilation in Lolium perenne colonized by the arbuscular mycorrhizal fungus Glomus fasciculatum. New Phytol. 138:411-417.

Hayakawa, T., K. Kamachi, M. Oikawa, K. Ojima, and T. Yamaya. 1990. Response of glutamine synthetase and glutamate synthase 
isoforms to nitrogen sources in rice cell cultures. Plant Cell Physiol. 31:1071-1077.

Hoagland, C.R. and D.I. Arnon. 1950. The solution culture method for growing plants without soil. California Agr. Expt. Circ. 347:1-32.

Jin, Z., C. Qian, J. Yang, H. Liu, and Z. Piao. 2007. Changes in activities of glutamine synthetase during grain filling and their relation to rice quality. Rice Sci. 14:211-216.

Kamachi, K., T. Yamaya, T. Mae, and K. Ojima. 1991. A role for glutamine synthetase in the remobilization of leaf nitrogen during natural senescence in rice leaves. Plant Physiol. 96:411-417.

Kavanová, M. and V. Gloser. 2005. The use of internal nitrogen stores in the rhizomatous grass Calamagrostis epigejos during regrowth after defoliation. Ann. Bot. (Lond.) 95:457-463.

Kumar, R.G., K. Shah, and R.S. Dubey. 2002. Salinity induced behavioural changes in malate dehydrogenase and glutamate dehydrogenase activities in rice seedlings of differing salt tolerance. Plant Sci. 156:23-34.

Kwinta, J., K. Bartoszewicz, and W. Bielawski. 2002. Effect of selected compounds on the activity of glutamate dehydrogenase from triticale roots. Acta Physiol. Plant. 24:279-283.

Kwinta, J. and W. Bielawski. 1998. Glutamate dehydrogenase in higher plants. Acta Physiol. Plant. 20:453-463.

Lam, H.M., K.T. Coschigano, I.C. Oliveira, R. Melo-Oliveira, and G.M. Coruzzi. 1996. The molecular-genetics of nitrogen assimilation into amino acids in higher plants. Annu. Rev. Plant Physiol. Plant Mol. Biol. 47:569-593.

Lasa, B., S. Frechilla, P.M. Aparicio-Tejo, and C. Lamsfus. 2002. Role of glutamate dehydrogenase and phosphoenolpyruvate carboxylase activity in ammonium nutrition tolerance in roots. Plant Physiol. Biochem. 40:969-976.

Lim, P.O., H.J. Kim, and H.G. Nam. 2007. Leaf senescence. Annu. Rev. Plant Biol. 58:115-136.

Liu, J., Y.H. Wu, J.J. Yang, Y.D. Liu, and F.F. Shen. 2008. Protein degradation and remobilization during leaf senescence. J. Plant Biol. 51:11-19.

Louahlia, S., P. Laine, J.H. MacDuff, A. Ourry, M. Humphreys, and J. Boucaud. 2008. Interactions between reserve mobilization and regulation of nitrate uptake during regrowth of Lolium perenne L.: Putative roles of amino acids and carbohydrates. Bot. 86:1101-1110.

Lu, B., Y. Yuan, C. Zhang, J. Ou, W. Zhou, and Q. Lin. 2005. Modulation of key enzymes involved in ammonium assimilation and carbon metabolism by low temperature in rice (Oryza sativa L.) roots. Plant Sci. 169:295-302.

Lyons, P.C., J.J. Evans, and C.W. Bacon. 1990. Effects of the fungal endophyte Acremonium coenophialum on nitrogen accumulation and metabolism in tall fescue. Plant Physiol. 92:726-732.

Machado, A.T., L. Sodek, E. Paterniani, and M.S. Fernandes. 2001. Nitrate reductase and glutamine synthetase activities in S1 endo- gamic families of the maize populations Sol da Manhã NF and Catetão. Rev. Bras. Fisiol. Vegetal 13:88-102.

McNally, S.F., B. Hirel, and G.R. Stewart. 1983. Nitrogen metabolism in halophytes. V. The occurrence of multiple forms of glutamine synthetase in leaf tissue. New Phytol. 94:47-56.

Miflin, B.J. and D.Z. Habash. 2002. The role of glutamine synthetase and glutamate dehydrogenase in nitrogen assimilation and possibilities for improvement in the nitrogen utilization of crops. J. Expt. Bot. 53:979-987.

Ourry, A., J. Boucaud, and J. Salette. 1990. Partitioning and remobilization of nitrogen during regrowth in nitrogen-deficient ryegrass. Crop Sci. 30:1251-1254.

Powell, C.E. and G.J.A. Ryle. 1978. Effect of nitrogen deficiency on photosynthesis and the partitioning of ${ }^{14} \mathrm{C}$-labelled leaf assimilate in unshaded and partially shaded plants of Lolium temulentum. Ann. Appl. Biol. 90:241-248.

Restivo, F.M. 2004. Molecular cloning of glutamate dehydrogenase genes of Nicotiana plumbaginifolia: Structure analysis and regulation of their expression by physiological and stress conditions. Plant Sci. 166:971-982.

Rhodes, D., G.A. Rendon, and G.R. Stewart. 1975. Control of glutamine synthetase level in Lemna minor L. Planta 125:201-211.

Shapiro, B.M. and E.R. Stadtman. 1970. Glutamine synthetase (Escherichia coli). Methods Enzymol. 17:910-922.

Skopelitis, D.S., N.V. Paranychianakis, A. Kouvarakis, A. Spyros, E.G. Stephanou, and K.A. Roubelakis-Angelakis. 2007. The isoenzyme 7 of tobacco $\mathrm{NAD}(\mathrm{H})$-dependent glutamate dehydrogenase exhibits high deaminating and low aminating activities in vivo. Plant Physiol. 145:1726-1734.

Sun, S., Y. Lin, Y. Weng, and M. Chen. 2006. Efficiency improvements on ninhydrin method for amino acid quantification. J. Food Compost. Anal. 19:112-117.

Teixeira, J. and F. Fidalgo. 2009. Salt stress affects glutamine synthetase activity and mRNA accumulation on potato plants in an organ-dependent manner. Plant Physiol. Biochem. 47:807-813.

Turano, F.J., R. Dashner, A. Upadhyaya, and C.R. Caldwell. 1996. Purification of mitochondrial glutamate dehydrogenase from darkgrown soybean seedlings. Plant Physiol. 112:1357-1364.

Wallsgrove, R.M., J.C. Turner, N.P. Hall, A.C. Kendall, and S.W.J. Bright. 1987. Barley mutants lacking chloroplast glutamine synthetaseBiochemical and genetic analysis. Plant Physiol. 83:155-158.

Yokohama, S. and J. Kiramatsu. 2003. A modified ninhydrin reagent using ascorbic acid instead of potassium cyanide. J. Biosci. Bioeng. 95:204-205.

Zozaya-Hinchliffe, M., C. Potenza, J.L. Ortega, and C. SenguptaGopalan. 2005. Nitrogen and metabolic regulation of the expression of plastidic glutamine synthetase in alfalfa (Medicago sativa). Plant Sci. 168:1041-1052. 